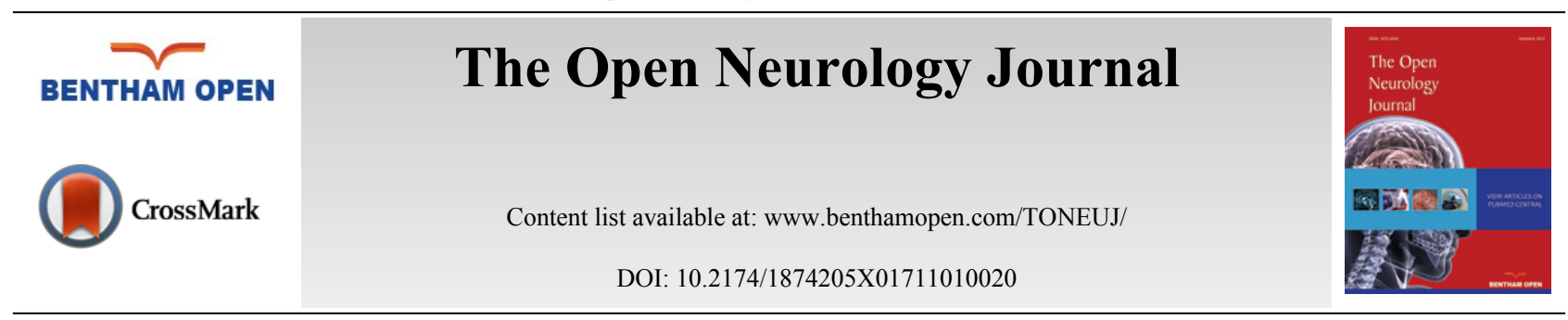

RESEARCH ARTICLE

\title{
Lumbar Spinal Angiolipoma with Expanding Left Neural Foramen Mimicking Lumbar Schwannoma; Case Report and Review of The Literature
}

Yener Akyuva ${ }^{1, *}$, Aylin Gonultas ${ }^{2}$, Numan Karaaslan ${ }^{3}, Z_{\text {Zhra Gulciftci Dagci }}{ }^{2}$, Semih Saglik ${ }^{4}$, Mehmet Isyar ${ }^{5}$ and Mahir Mahirogullari ${ }^{6}$

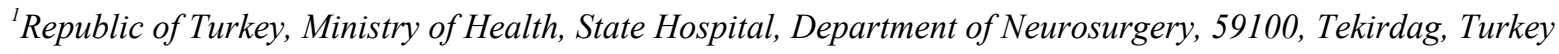

${ }^{2}$ Republic of Turkey, Ministry of Health, State Hospital, Department of Pathology, 59100, Tekirdag, Turkey

${ }^{3}$ Namik Kemal University School of Medicine, Department of Neurosurgery, 59030, Tekirdag, Turkey

${ }^{4}$ Republic of Turkey, Ministry of Health, State Hospital, Department of Radiology, 56100, Siirt, Turkey

${ }_{5}^{5}$ Medicalpark Bahcelievler, Department of Orthopaedic and Traumatology, 34050, Istanbul, Turkey

${ }^{6}$ Istanbul Memorial Health Group, Department of Orthopaedic and Traumatology, 34758, Istanbul, Turkey

Received: May 01, 2017

Revised: July 09, 2017

Accepted: August 09, 2017

\section{Abstract:}

Aim:

To describe a patient with lumbar angiolipoma mimicking schwannoma in the posterolateral side of the spinal canal with expansion of the left lumbar foramen and to discuss the clinical, radiologic, and surgical features of these lesions with literature.

\section{Methods:}

Without language restriction in this paper, the electronic databases; The Cochrane Collaboration the Cochrane, The Cochrane Library (Issue 2 of 12, Feb. 2011), ProQuest, US National Library of Medicine, National Institutes of Health (NLM) and PubMed dating from 1966 September to January Week 2 2017, were searched for comparative experimental studies using the terms: "OR", "AND”. On-line literature searches were conducted using the key words "lumbar angiolipoma", "schwannoma ", "spinal angiolipoma", "spinal cord", and "spinal canal". We compared this research with our patient.

Results:

Bilateral L2 total laminectomy, excision of the tumors and bilateral L2-L3 transpedicular stabilization were performed, and complaints improved prominently. Pathological examination was reported as angiolipoma.

\section{Conclusion:}

The research shows that a probable diagnosis in such tumor cases could be made by sufficient pre-op scanning before surgical operations and although angiolipoma has been rarely seen in lumbar posterolateral space, it can be seen in lumbar region and mimic schwannoma as producing symptoms and signs of spinal cord and nerve root compression.

Keywords: Lumbar angiolipoma, Schwannoma, Spinal angiolipoma, Spinal cord, Spinal canal.

\section{INTRODUCTION}

Angiolipoma is a frequent benign lipomatosis tumor comprising of mature fatty tissue and vascular proliferation.

* Address correspondence to this author at the Republic of Turkey Ministry of Health - Neurosurgery Tekirdag, Turkey Neurosurgery, Turkey; Tel: +905066726959; Fax: +902822603850; E-mail: yenerakyuva@hotmail.com 
They generally occur under the skin. 2/3 of the cases are forearm based. Besides, they locate in the body and arm [1]. Angiolipoma is rarely seen in the spinal canal $[2,3]$.

Spinal angiolipoma is a rare specific clinicopathologic entity, which is to be distinguished from skin angiolipoma [3]. Spinal angiolipomas comprises $0.04 \%-1.2 \%$ of all spinal cord tumors and spinal $2-3 \%$ of extradural tumors [2, 4 7]. Most of spinal angiolipomas are seen in thoracic region of posterior extradural areas $[5,8]$. Lumbar spinal angiolipomas are rarely seen and comprise $9.6 \%$ of all spinal angiolipomas [5, 9, 10]. Besides, lumbar spinal angiolipomas are frequently seen in anterior extradural locations [9].

Spinal angiolipomas do not often show infiltration, yet in some cases, infiltration to soft surrounding tissues and bone may occur $[9,11]$. Since angiolipoma is rarely seen in the spinal canal, it may not be noticed in the evaluation of lesions in this area [8]. It may sometimes mimic a malign tumor due to its infiltrative appearance in soft surrounding tissues and vertebra $[8,12]$. Also, hydatid cyst, neurofibroma and hemangioma should be kept in mind as a differential diagnosis [13 - 15].

Angiolipoma with lumbar posterolateral location is an extremely rare tumor $[8,11]$. In posterolateral location of lumbar region at spinal canal most frequently encountered primary tumor is schwannoma [16 - 18]. However, when the full texts of these researches are analyzed, it is not found that, as in our study, angiolipoma mimics lumbar schwannoma due to surrounding lumbar root and expanding neural foramen.

Schwannoma, which is known as norilemma, is based on benign peripheral nerve sheath stemming from a schwann cell. This is the most common solitary tumor of the peripheral nerves $[16,18]$. Malignant degeneration of the schwannoma is very rare, yet there are few reports in which malign transformation is mentioned. Schwannoma, which can be seen in every area of extradural peripheral nerves, is frequently seen in the nerve root in the extradural space [10, $18]$.

The present study aimed to analyze the patient that mimics lumbar schwannoma, which is extradural posterolateral located in the lumbar area before the operation. In addition, it was intended to indicate spinal angiolipoma case, which arose suspicion regarding its malignity, along with a literature review as they infiltrated to adjacent bone and soft tissues which were seen during the operation.

\section{CASE REPORT}

The patient was a 65 -year-old-woman with body mass index $23 \mathrm{~kg} / \mathrm{m}^{2}$. The history of smoking and alcohol did not present in the patient. The patient was referred to our clinics with back pain and having difficulty in walking due to weakness in her left leg which had aggravated last 3 months. After careful anamnesis, it was found that the patient had a history of the left hemiparesis that had started one year ago, due to the right-sided thalamic cerebrovascular occlusion. However, during the neurological examination, it was discovered that lower extremity weakness was relatively more significant than that was seen in the upper extremity.

While nearly normal muscle strength was found due to cerebrovascular occlusion in the left upper extremity, $3 / 5$ muscular force was detected in the left lower extremity of proximal extensor muscle groups. The patient had difficulty of knee extension which suggested primarily a pathology of L3 nerve root. Following examination of positive leg test, it was discovered that there was a motor deficit in lower extremity.

In laboratory tests, no result was observed to consider hematologic malignity. However, it was not excluded the fact that the pathologic diagnosis was crucial for lymphoma. The biological and hormone values were found to be in the limits.

A Magnetic Resonance Image (MRI) scan of the patient was immediately taken and a tumor was seen in L2-L3 disc level. It was in the left posterolateral extradural area and its long axis was parallel to the spinal cord.

The tumor diameter was $3.2 \mathrm{~cm}$ in craniocaudal plane and it shrank on both sides. Anteroposterior diameter was 0.8 $\mathrm{cm}$ on the largest zone and the dural sac was found to be compressed slightly and postero-laterally by this mass (Figs. 1A-1C). Moreover, there were heterogeneous hyperintensity in T1 and T2 weighted images detected on MRI, which expanded along left L2-L3 neural foramen causing extension in neural foramen whereas there were hypo intense focuses on T2-weighted images (Figs. 1A and 1C). Following contrast agent administration, in T1-weighted fat suppressed images, it was found that there was a lesion in which there was an intensive contrast enhancement.

The lumbar computed tomography (CT) of the patient was also performed, it was found that lesion was seen 
isodense with spinal cord and caused extension in the left L2-L3 neural foramen and stenosis of the spinal canal (Fig. 1D). The patient was diagnosed with the tumor, which was thought to be schwannoma or lymphoma before the operation. Tumor excision was then performed and stabilization was ensured by using bilateral L2 total laminectomy, left L2/L3 facetectomy technique and bilateral L2-L3 transpedicular screw rod system [18, 19].
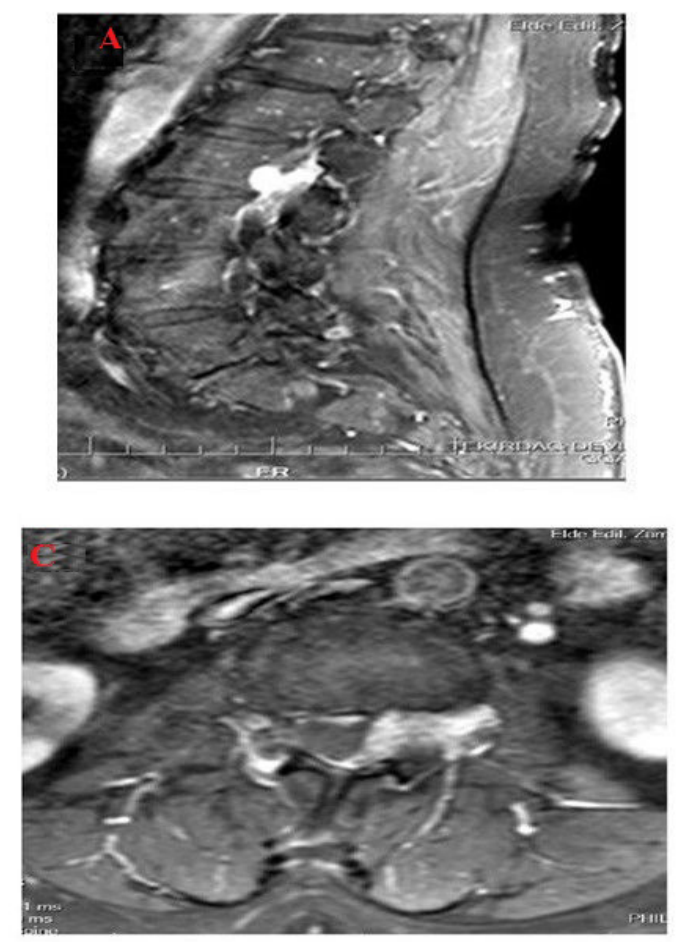
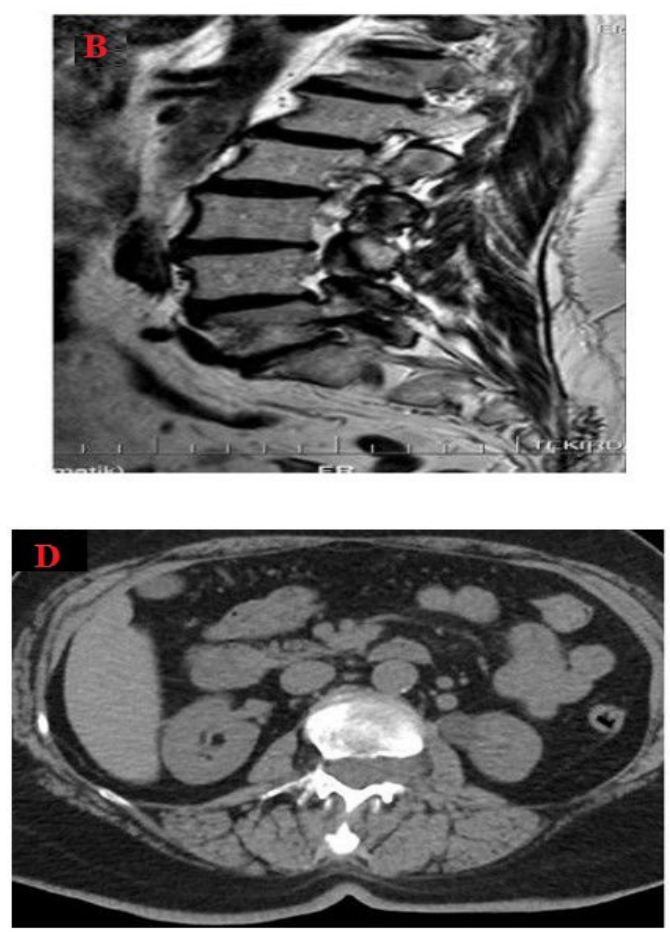

Fig. (1). Radiological findings of patient with left L2-3 postero-lateral angiolipoma.

The material excised after the operation was transferred to the laboratory in a container with $10 \%$ formol solution to realize histopathological examination. It was found in the macroscopic examination that the materials were comprised of five yellow-pink bleeding tissues sized from 0.8 to $0.2 \mathrm{~cm}$. The full extent of the material was sampled. The tissue pieces were embedded in paraffin blocks after follow-up. Five micrometer sections were taken from paraffin-embedded tissues, stained using the Hematoxylin and Eosin (H\&E) and examined under the light microscope.
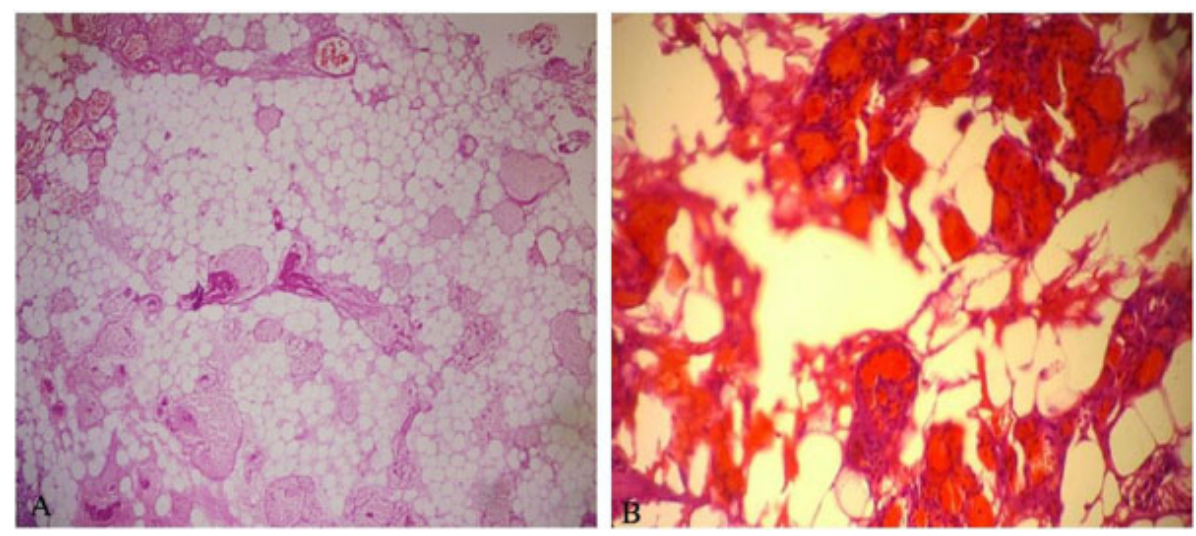

Fig. (2). $\boldsymbol{A}$; Fibrine thrombus inside vascular component and mature lipoid tissue (Magnification; x4, H\&E). B; Mature lipoid tissue between vascular component with congestion (Magnification; $\mathrm{x} 20, \mathrm{H} \& \mathrm{E}$ ).

Cautery artefact was seen in tissue fragments during histological examination. Besides, mature adipose tissue and tumor composed of abnormal vascular proliferation were mostly seen in the capillary structure. Fibrin thrombus was also the case in lumens of some capillary vessels. There wasn't atypia and mitosis but abundant adipose tissue was seen 
in component of resected tumor tissue (Figs. $\mathbf{2 A}$ and $\mathbf{2 B}$ ).

In immunohistochemically examination, cluster of differentiation (CD)-34 and S100 were detected as well as positive stain. Stain with LCA and pancytokeratin were not detected. The Ki-67 proliferation index was found low.

The patient was evaluated in line with angiolipoma. There weren't infiltration of extradural soft tissues and bone.

\section{DISCUSSION WITH LITERATURE REVIEW}

The first spinal angiolipoma case was reported in 1890 by Berenbruch [3, 28]. Howard and Helwig defined angiolipoma as a clinicopathologic entity including vascular and mature adipose elements in 1960 [2, 4].

Lin et al. divided spinal angiolipoma into two groups: noninfiltrative and infiltrative [4, 7]. The noninfiltrating spinal angiolipomas are frequently encapsulated and occur mostly in the posterior extradural space of the spinal cord. The infiltrating types are rarely seen and partly or completely unencapsulated. They are located in the anterior and anterolateral extradural space of the spinal cord [7]. The prognosis of the noninfiltrating spinal angiolipomas is better than infiltrating types and they have an unfavorable prognosis $[2,4]$.

The histogenesis of angiolipomas are not known. These tumors are most likely to be caused by abnormal primitive pluripotential mesenchymal cells which are differentiating in lipomatosis, angiomatous and mix tissues [2]. Tumor is macroscopically encapsulated or unencapsulated red soft tissue in pathologic evaluation [20].

In histological incisions, mature adipocytes and vessel proliferation comprised of vessels at the size of branching capillary are seen [1]. In some parts of vessels, there are fibrin thrombus as diagnostic characteristic. There are distinctive mast cells in angiolipomas. Fibrin thrombus and mast cells are morphologic findings, which is a distinctive characteristic from lipoma [3].

In tumor, the rate of fat tissue to the vascular compartment ranges between $1 / 3$ and $2 / 3$ [7, 8, 21]. Vascular structures in some angiolipomas comprise almost the whole of the tumor. These tumors that are called 'cellular angiolipoma' are to be separated from kaposi sarcoma and angiosarcoma [1]. It is different from these tumors because lipoid tissue, pleomorphism, atypia and mitosis are not seen in angiolipoma [6, 20].

Immunohistochemical examination from the literature was performed in some cases and Ki-67 index is also lower in angiolipoma $[6,20,22]$. Spinal angiolipomas are generally seen between the ages of 40 and 60 and especially in women $[6,7]$. There are few cases seen in children [2].

Almost all spinal angiolipomas are localized in extradural site. Most of these extradural angiolipomas are in posterior part in thoracic site [11]. Thoracolumbar component and pure lumbar localization is rare [22]. Tumors in lumbar area generally locate in anterior of spinal canal [11]. Today MRI is the most appropriate device in diagnosing angiolipomas. In MRI angiolipomas are mostly seen heterogenous hypo intense in T1-weighed examination on extradural area. In T2-weighted examination, fatty components are seen as hyper intense and vascular areas as hypo intense. More specifically, after contrast agents such as gadolinium are administered, lipoid layer and vascular flow openings are seen, which become distinctive in T1-weighted images [23, 24]. Schwannoma is seen heterogeneously hyperintense in T2-weighted images and intense contrast enhancement in T1 weighted images [16, 19$].$

In literature, it is reported that typical angiolipoma is radiolucent in both plain radiography and CT. In addition, CT is adjuvant imaging method since vascular enclosing radiolucent may contain calcific sites [25, 26]. Also, schwannoma may have calcific foci on CT and intense contrast enhancement is usually seen $[16,18]$.

MRI and CT devices were used in order to diagnose the patient in the present study. Similar images that had been defined were seen in MRI images that were carried out by contrasted pharmacologic agents (Figs. 1A and 1D). Also, CT show isodense mass with calcific foci expanding left neural foramen. L2 vertebrae foraminal enlargement could be understood on plain film. Multi-modality imaging should be performed on spinal epidural angiolipoma as well as on the breast [17].

Patient of this case had no family history, skin neurofibroma, 'cafe-au-lait spots' skin lesions, Lisch Nodule or optic glioma, but neurofibroma had not excluded with a low differential diagnosis. Because neurofibroma and as well as schwannoma may have similar radiological appearance on CT and MRI.

Angiolipomas cannot be easily excised like lipoma because they are slim with irregular capsule. Wide local excision of angiolipoma minimizes the risk of relapse. Wide resection may require excision of a significant part of healthy tissue containing critical neurovascular structures. Excision of an important nerve or vessel is to be operated by considering 
high incidence of local recurrence of the tumor that was insufficiently excised with the purpose of gain wider bounds. For this reason, the surgery should be individualized [27].

Application of tumor excision by laminoplasty and/or laminectomy in the area of tumor is a standard treatment modality in extradural located angiolipoma operations [28, 29].

However, in literature, in the surgery of tumors with extraforaminal component, it is emphasized that facetectomy might be applied in treatment of tumors for the extraforaminal component. Afterwards, stabilization is recommended using transpedicular screw in order to prevent lumbar instability after tumor excision [19, 30]. Unlike the cases in the literature who were operated the patient in the present study was performed excision as the secondary technique since operated tumor surrounded lumbar root and had extraforaminal component by expanding neural foramen, thus imitating lumbar schwannoma.

Also, the pre-operative malign tumor was suspected because of invasive radiological appearance, marginal resection of the tumor was planned and carried out in this patient. So that posterior transpedicular stabilization should had done.

In literature, there are some studies indicating that malign transformation of angiolipomas may rarely seen [27]. Although preoperative radiological findings consisted with malignancy, it was reported that there wasn't malignity in the excised tumor tissue. Yamashita et al. studied characterization of histological types in order to contribute to treatment modalities in spinal cord tumors before operations [31]. Similarly, pre-op MRI was used when diagnosing the patient in our study. Besides, postop excised tissue material was evaluated histopathologically.

\section{CONCLUSION}

As a result, it was found that a probable diagnosis in such tumor cases could be made by sufficient pre-op scannings before surgical operations and total excision and full treatment could be sustained by means of correct surgical techniques. Although angiolipoma has been rarely seen in lumbar posterolateral space, it can be seen in lumbar region and mimic schwannoma as producing symptoms and signs of spinal cord and nerve root compression.

\section{ETHICS APPROVAL AND CONSENT TO PARTICIPATE}

Written permission was obtained from local ethic committee. Additional informed consent form was also taken from the case in the framework of the Declaration of Helsinki.

\section{HUMAN AND ANIMAL RIGHTS}

This study was carried out in accordance with the declaration of helsinki and with written consent of the patient.

\section{CONSENT FOR PUBLICATION}

Not applicable.

\section{CONFLICT OF INTEREST}

The author declare no conflicts of interest. All authors certify that neither they nor members of their immediate family have funding interests or commercial associations (e.g., consultancies, stock ownership, equity interest, patent/licensing arrangements, etc.) that may pose a conflict of interest in connection with the submitted article.

\section{ACKNOWLEDGEMENTS}

We are thankful to Medical Pharmacologist \& Pharmacist Ibrahim Y1lmaz of the Istanbul University School of Medicine, Department of Medical Pharmacology for made suggested revisions for grammar, word choice, wordiness, awkward phrases, and clarity, etc. as an independent individual.

\section{REFERENCES}

[1] Fletcher CD, Unni KK, Mertens F. Pathology and genetics of tumours of soft tissue and bone. 2002; 4: p. 28.

[2] Bouali S, Maatar N, Bouhoula A, et al. Spinal epidural angiolipomas: Clinical characteristics, management and outcomes. Asian J Neurosurg 2016; 11(4): 348-51.

[http://dx.doi.org/10.4103/1793-5482.180901] [PMID: 27695535]

[3] Goldblum JR, Weiss SW, Folpe AL. Enzinger and Weiss's soft tissue tumors. $4^{\text {th }}$ ed. Elsevier Health Sciences 2001 ; p. 582. 
[4] Mohammed ZI, Ahmed MM. Spinal extradural angiolipoma manifested after normal vaginal delivery. BMC Res Notes 2016; 9(1): 132. [http://dx.doi.org/10.1186/s13104-016-1944-3] [PMID: 26928853]

[5] Nadi MM, Nadi AM, Zabara MY, Ahmad TM. Management of infiltrating spinal epidural angiolipoma. Neurosciences 2015; 20 (2): 159-63. [http://dx.doi.org/10.17712/nsj.2015.2.20140463] [PMID: 25864069]

[6] Si Y, Wang Z, Pan Y, Lin G, Yu T. Spinal angiolipoma: etiology, imaging findings, classification, treatment, and prognosis. Eur Spine J 2014; 23(2): 417-25.

[http://dx.doi.org/10.1007/s00586-013-3073-1] [PMID: 24190280]

[7] Wang B, Yang Z, Yang J, Wang G, Xu Y, Liu P. Spinal angiolipoma: experience of twelve patients and literature. Neurol India 2014; 62(4): 367-70. [http://dx.doi.org/10.4103/0028-3886.141232] [PMID: 25237940]

[8] Benvenutti-Regato M, De la Garza-Ramos R, Caro-Osorio E. Thoracic epidural spinal angiolipoma with coexisting lumbar spinal stenosis: Case report and review of the literature. Int J Spine Surg 2015; 9: 67. [http://dx.doi.org/10.14444/2067] [PMID: 26767159]

[9] Dogan S, Arslan E, Sahin S, Aksoy K, Aker S. Lumbar spinal extradural angiolipomas. Two case reports. Neurol Med Chir 2006; 46(3): $157-60$

[http://dx.doi.org/10.2176/nmc.46.157] [PMID: 16565587]

[10] Isla A, Ortega Martinez R, Pérez López C, Gómez de la Riva A, Mansilla B. Lumbar spinal angiolipoma. Neurocirugia 2016; $27(5)$ : 258-62. [http://dx.doi.org/10.1016/j.neucir.2016.02.011] [PMID: 27263067]

[11] do Souto AA, Domingues FS, Chimelli L, Lemos AM. Lumbosacral angiolipoma: case report. Arq Neuropsiquiatr 2003; 61(2A): 269-73. [http://dx.doi.org/10.1590/S0004-282X2003000200021] [PMID: 12806510]

[12] Rivkind A, Margulies JY, Lebensart P, Sherman Y, Robin GC. Anterior approach for removal of spinal angiolipoma. A case report. Spine 1986; 11(6): 623-5.

[http://dx.doi.org/10.1097/00007632-198607000-00016] [PMID: 3787328]

[13] Aslan S, Bekci T, Aslan K, Gunbey HP, Incesu L, Akyuz B. A rare cause of chronic backache: paraspinal hydatid cyst with neural foraminal extension. Spine J 2015; 15(11): e13-4. [http://dx.doi.org/10.1016/j.spinee.2015.06.042] [PMID: 26096488]

[14] Gunbey HP, Bekci T, Aslan K, Ozturk M, Incesu L. Solitary anterior cervical canal neurofibroma causing neck pain. Spine J 2016; 16(3): e171. [http://dx.doi.org/10.1016/j.spinee.2015.10.002] [PMID: 26471706]

[15] Ozturk M, Bekci T, Aslan K, Gunbey HP, Incesu L. Thoracic spinal epidural capillo-cavernous hemangioma causing back pain. Spine J 2016; 16(3): e147.

[http://dx.doi.org/10.1016/j.spinee.2015.09.054] [PMID: 26471705]

[16] Celli P, Trillò G, Ferrante L. Spinal extradural schwannoma. J Neurosurg Spine 2005; 2(4): 447-56. [http://dx.doi.org/10.3171/spi.2005.2.4.0447] [PMID: 15871485]

[17] Ozturk M, Polat AV, Bekci T, Sullu Y. Angiolipoma of the breast: Multi-modality imaging findings. Breast J 2016; 22(6): 698-700. [http://dx.doi.org/10.1111/tbj.12667] [PMID: 27509032]

[18] Seppälä MT, Haltia MJ, Sankila RJ, Jääskeläinen JE, Heiskanen O. Long-term outcome after removal of spinal schwannoma: a clinicopathological study of 187 cases. J Neurosurg 1995; 83(4): 621-6. [http://dx.doi.org/10.3171/jns.1995.83.4.0621] [PMID: 7674010]

[19] Safaee M, Oh T, Barbaro NM, et al. Results of spinal fusion after spinal nerve sheath tumor resection. World Neurosurg 2016; 90: 6-13. [http://dx.doi.org/10.1016/j.wneu.2016.01.015] [PMID: 26802866]

[20] Gelabert-González M, García-Allut A. Spinal extradural angiolipoma: report of two cases and review of the literature. Eur Spine J 2009; 18(3): 324-35. [http://dx.doi.org/10.1007/s00586-008-0858-8] [PMID: 19127373]

[21] Hu S, Hu CH, Hu XY, et al. MRI features of spinal epidural angiolipomas. Korean J Radiol 2013; $14(5): 810-7$. [http://dx.doi.org/10.3348/kjr.2013.14.5.810] [PMID: 24043978]

[22] Sim K, Tsui A, Paldor I, Kaye AH, Gaillard F. Four cases of spinal epidural angiolipoma. J Clin Neurosci 2016 ; 25 : 134-9. [http://dx.doi.org/10.1016/j.jocn.2015.08.028] [PMID: 26778809]

[23] Garg A, Gupta V, Gaikwad S, et al. Spinal angiolipoma: report of three cases and review of MRI features. Australas Radiol 2002; 46(1): 84-90. [http://dx.doi.org/10.1046/j.1440-1673.2001.01001.x] [PMID: 11966595]

[24] Provenzale JM, McLendon RE. Spinal angiolipomas: MR features. AJNR Am J Neuroradiol 1996; 17(4): 713-9. [PMID: 8730192]

[25] Matsushima K, Shinohara Y, Yamamoto M, Tanigaki T, Ikeda A, Satoh O. Spinal extradural angiolipoma: MR and CT diagnosis. J Comput Assist Tomogr 1987; 11(6): 1104-6. [http://dx.doi.org/10.1097/00004728-198711000-00047] [PMID: 3680705] 
[26] Weill A, del Carpio-O’Donovan R, Tampieri D, Melanson D, Ethier R. Spinal angiolipomas: CT and MR aspects. J Comput Assist Tomogr 1991; 15(1): 83-5.

[http://dx.doi.org/10.1097/00004728-199101000-00011] [PMID: 1987206]

[27] Ingari JV, Faillace JJ. Benign tumors of fibrous tissue and adipose tissue in the hand. Hand Clin 2004; 20 (3): $243-8$. [http://dx.doi.org/10.1016/j.hcl.2004.03.013] [PMID: 15275683]

[28] Guzey FK, Bas NS, Ozkan N, Karabulut C, Bas SC, Turgut H. Lumbar extradural infiltrating angiolipoma: a case report and review of 17 previously reported cases with infiltrating spinal angiolipomas. Spine J 2007; 7(6): 739-44. [http://dx.doi.org/10.1016/j.spinee.2006.08.014] [PMID: 17998134]

[29] Montano N, Trevisi G, Cioni B, et al. The role of laminoplasty in preventing spinal deformity in adult patients submitted to resection of an intradural spinal tumor. Case series and literature review. Clin Neurol Neurosurg 2014; 125: 69-74. [http://dx.doi.org/10.1016/j.clineuro.2014.07.024] [PMID: 25108286]

[30] Nanda A, Kukreja S, Ambekar S, Bollam P, Sin AH. Surgical strategies in the management of spinal nerve sheath tumors. World Neurosurg 2015; 83(6): 886-99.

[http://dx.doi.org/10.1016/j.wneu.2015.01.020] [PMID: 25655687]

[31] Yamashita K, Fuji T, Nakai T, Hamada H, Kotoh K. Extradural spinal angiolipoma: report of a case studied with MRI. Surg Neurol 1993; 39(1): 49-52.

[http://dx.doi.org/10.1016/0090-3019(93)90110-M] [PMID: 8451720]

(C) 2017 Akyuva et al.

This is an open access article distributed under the terms of the Creative Commons Attribution 4.0 International Public License (CC-BY 4.0), a copy of which is available at: https://creativecommons.org/licenses/by/4.0/legalcode. This license permits unrestricted use, distribution, and reproduction in any medium, provided the original author and source are credited. 